Article

\title{
Effect of Nitrate and Perchlorate on Selenate Reduction in a Sequencing Batch Reactor
}

\author{
Hyun-Woo Kim ${ }^{1}\left[\right.$, Seong Hwan Hong ${ }^{2}$ and Hyeoksun Choi ${ }^{3, * \mathbb{C}}$ \\ 1 Department of Environmental Engineering, Soil Environment Research Center, Jeonbuk National University, \\ Jeonju 54896, Korea; hyunwoo@jbnu.ac.kr \\ 2 Gangto Engineering Co. Ltd., Anyang 14058, Korea; hmh5hot@naver.com \\ 3 Department of Civil and Environmental Engineering, Wonkwang University, Iksan 54538, Korea \\ * Correspondence: choihs@wku.ac.kr; Tel.: +82-63-850-6713
}

Received: 12 February 2020; Accepted: 13 March 2020; Published: 16 March 2020

\begin{abstract}
Selenate removal from a water body is being vigorously debated owing to severe health impact, but inhibitions of coexisting anions have been reported. To suggest a viable treatment option, this study investigates the effect of nitrate and perchlorate on selenate reduction in a laboratory-scale sequencing batch reactor. The experimental design tests how competing electron acceptors $\left(\mathrm{NO}_{3}{ }^{-}\right.$ and $\mathrm{ClO}_{4}^{-}$) and electron donor (acetate) limitations affect selenate reduction in the reactor. Results show that the reactor achieves almost complete selenate reduction within the initial concentration ranges of $0.1-1 \mathrm{mM}$ by enriching selenate-reducing bacteria with appropriate temperature $\left(30^{\circ} \mathrm{C}\right)$ and acclimation period (50 days). We monitored simultaneous selenate and nitrate reduction in the reactor without specific inhibition due to a difference in microbial growth strategy related to electron donor status. Lack of perchlorate-reducing bacteria makes perchlorate addition $(0.2 \mathrm{mM})$ not to be closely associated with dissimilative perchlorate reduction. These results provide information that can help us to understand the effect of competing electron acceptors on selenate reduction and the kinetics of potential parallel reactions in the reactor.
\end{abstract}

Keywords: biological selenate reduction; electron donor competition; nitrate; perchlorate; sequencing batch

\section{Introduction}

Selenium (Se) is an essential micronutrient but can cause adverse health effects (e.g. hair loss, fingernail loss, numbness in fingers or toes, and circulatory problems) with long-term and heavy exposure [1,2]. Since Se in water originates from not only geological sources such as weathering of seleniferous soils/rocks but also anthropogenic processes such as mining, fossil fuel combustion, and other industrial activities [3], the World Health Organization has set a provisional total Se guideline of $40 \mu \mathrm{g} / \mathrm{L}$ in drinking water [4]. The United States Environmental Protection Agency permits the maximum concentration limit (MCL) of total Se as $50 \mu \mathrm{g} / \mathrm{L}$ and the regulations of national primary drinking water as $5 \mu \mathrm{g} / \mathrm{L}$ [2]. Likewise, the Korean Ministry of Environment is reducing the MCL to $10 \mu \mathrm{gSe} / \mathrm{L}$ in drinking water [5].

Se has four oxidation states (-II, 0, IV, VI) and forms several organic complexes [6]. In surface water, most Se primarily exists either selenate $\left(\mathrm{SeO}_{4}{ }^{2-}\right)$ or selenite $\left(\mathrm{SeO}_{3}{ }^{2-}\right)$. Both oxyanions are toxic to living organisms thus various treatment technologies have been investigated to remove Se from water [7]. Although physicochemical technologies effectively separate Se from the water supplied for domestic and industrial use, eventual post-treatments for the byproducts are required and technical limitations are still existing [8]. Fortunately, biological treatment can reduce selenate and selenite 
to insoluble elemental Se $\left(\mathrm{Se}^{0}\right)$ via anaerobic microbial metabolisms [6,9]. From a wide variety of environments, selenate- or selenite-reducing bacteria have been isolated [10,11].

When selenate or selenite coexist with other anions such as nitrate $\left(\mathrm{NO}_{3}{ }^{-}\right)$, sulfate $\left(\mathrm{SO}_{4}{ }^{2-}\right)$, and perchlorate $\left(\mathrm{ClO}_{4}^{-}\right)$, biological Se reduction can be inhibited by the electron scavenging of denitrifying bacteria, sulfate-reducing bacteria, or perchlorate-reducing bacteria because most selenate-reducing bacteria are heterotrophic facultative anaerobes which compete for electron donors under anoxic or anaerobic conditions. Another limiting factor might be the drastic change of selenate in the water body due to irrigated agricultural drainage [11], sedimentary soil erosion [3], surface mining [12], coal-fired power plants [13], and so on.

Most biological selenate reductions are targeted for either pure culture or up-flow anaerobic sludge blanket process [14]. Relatively little reports are available about the simultaneous reduction of selenate in a mixed culture when competing anions exist [14-17]. This study, therefore, investigates the feasibility of simultaneous selenate, nitrate, and perchlorate reduction in a sequencing batch reactor (SBR) and evaluate the inhibitory effects of nitrate and perchlorate on biological selenate reduction.

\section{Materials and Methods}

\subsection{Selective Enrichment of Selenate-Reducing Bacteria}

To selectively enrich selenate-reducing bacteria, bench-scale SBRs were semi-continuously operated in parallel for more than one and a half months. Seed sludge was activated sludge taken from a local municipal wastewater treatment plant with a treatment capacity of $30,000 \mathrm{~m}^{3} / \mathrm{d}$ in the northern part of I-city, Korea. Using selenate as a sole electron acceptor, the enrichment period was kept under anoxic conditions. To support selective pressure on selenate-reducing bacteria, the temperature was controlled to $30^{\circ} \mathrm{C}$ by aquarium heaters following previous literature [18].

\subsection{Operating Condition of SBRs}

Figure 1 shows the schematic diagram of the triplicate SBRs. The working volume of each SBR was $5 \mathrm{~L}$. To verify the proper temperature condition $\left(25^{\circ} \mathrm{C}\right.$ and $\left.30^{\circ} \mathrm{C}\right)$, SBRs were continuously monitored for more than $200 \mathrm{~h}$ until complete selenate reduction at the first batch. And then all the reactors were operated with $24 \mathrm{~h}$ sequence with the optimal temperature condition using the pre-acclimated biomass for $30^{\circ} \mathrm{C}$. Each SBR was completely mixed for $23 \mathrm{~h}$. And then, an hour of settling period followed by rapid draw sequence of the upper liquid $(2.5 \mathrm{~L})$ and fill sequence with fresh feed solution. The feed solution contains selenate, acetate $\left(\mathrm{CH}_{3} \mathrm{COO}^{-}\right)$, buffer, and essential minerals: $50 \mathrm{mg} / \mathrm{L}$ of $\mathrm{SeO}_{4}{ }^{2-}$, $200 \mathrm{mg} / \mathrm{L}$ of $\mathrm{CH}_{3} \mathrm{COO}^{-}, 46 \mathrm{mg} / \mathrm{L}$ of $\left(\mathrm{NH}_{4}\right)_{2} \mathrm{SO}_{4}, 13.7 \mathrm{mg} / \mathrm{L}$ of $\mathrm{K}_{2} \mathrm{HPO}_{4}, 84 \mathrm{mg} / \mathrm{L}$ of $\mathrm{NaHCO}_{3}, 51.3 \mathrm{mg} / \mathrm{L}$ of $\mathrm{MgSO}_{4} \cdot 7 \mathrm{H}_{2} \mathrm{O}, 43 \mathrm{mg} / \mathrm{L}$ of $\mathrm{CaSO}_{4} \cdot 2 \mathrm{H}_{2} \mathrm{O}$, and $2.5 \mathrm{mg} / \mathrm{L}$ of $\mathrm{FeSO}_{4} \cdot 7 \mathrm{H}_{2} \mathrm{O}$. Other micronutrients were available from inoculum and endogenous cell decay. Acetate was a sole carbon source (electron donor). To test the effects of nitrate and perchlorate on selenate reduction, we designed the experiments as shown in Table 1. 


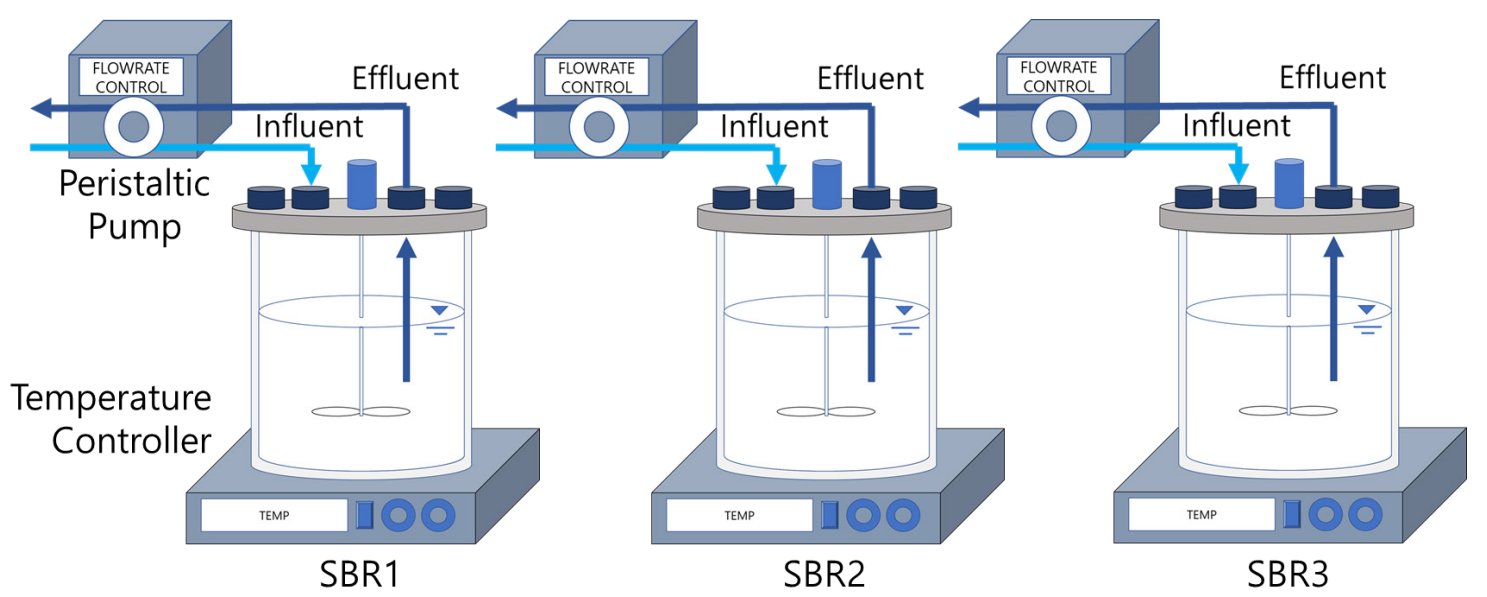

Figure 1. Schematic diagram of triplicate sequencing batch reactors (SBRs).

Table 1. Operating conditions of SBRs according to experimental design.

\begin{tabular}{|c|c|c|c|c|c|}
\hline \multirow{2}{*}{ Division } & \multicolumn{4}{|c|}{ Initial Concentration of Target Contaminants } & \multirow{2}{*}{$\begin{array}{c}\mathrm{C}: \mathrm{N} \\
\left(\mathrm{CH}_{3} \mathrm{COO}^{-}-\mathrm{C}:\right. \\
\left.\mathrm{NO}_{3}-\mathrm{N}\right)\end{array}$} \\
\hline & $\begin{array}{c}\text { Selenate } \\
\left(\mathrm{mM} \mathrm{SeO}_{4}{ }^{2-}\right)\end{array}$ & $\begin{array}{c}\text { Nitrate } \\
\left(\mathrm{mM} \mathrm{NO}_{3}^{-}\right)\end{array}$ & $\begin{array}{l}\text { Perchlorate } \\
\left(\mathrm{mM} \mathrm{ClO}_{4}^{-}\right)\end{array}$ & $\begin{array}{c}\text { Acetate } \\
\left(\mathrm{mM} \mathrm{CH}_{3} \mathrm{COO}^{-}\right)\end{array}$ & \\
\hline Phase $0^{\mathrm{a}}$ & 0.35 & 0.00 & 0.0 & 3.4 & N.A. \\
\hline Phase 1 & 0.1 & 1.0 & 0.0 & 3.4 & 6.7: 1 \\
\hline Phase 2 & 1.0 & 1.0 & 0.0 & 5.1 & 11.1: 1 \\
\hline Phase 3 & 0.1 & 1.0 & 0.0 & 0.6 & 1.2: 1 \\
\hline Phase 4 & 1.0 & 1.0 & 0.0 & 0.9 & 2.3: 1 \\
\hline Phase 5 & 0.1 & 1.0 & 0.2 & 3.4 & 5.8: 1 \\
\hline
\end{tabular}

\subsection{Analytical Methods}

Influent and effluent liquid samples were filtered using a $0.2 \mu \mathrm{m}$ syringe filter (Whatman, GE Healthcare Life Sciences, Marlborough, MA, USA) and kept in a refrigerator at $4{ }^{\circ} \mathrm{C}$ before analysis. Selenate was determined by using an ion chromatograph (Dionex ICX-1100, Dionex, Sunnyvale, CA, USA) equipped with an IonPac AS15 analytical column and AG15 guard column. The used eluent was a $36.5 \mathrm{mM} \mathrm{NaOH}$ solution (Daejung Chemicals, Siheung, Korea). The volume of the used sample loop for selenate determination was $100 \mu \mathrm{L}$. For perchlorate determination, we used the same ion chromatograph equipped with IonPac AS16 analytical column and AG16 guard column (Dionex, Thermo Fisher Scientific, Waltham, MA, USA). In this case, we used the sample loop volume of $1000 \mu \mathrm{L}$ with the same $50 \mathrm{mM} \mathrm{NaOH}$ eluent. Nitrate and acetate concentrations were monitored by using an IonPac AS9-HC analytical and AG9-HC guard column with $9 \mathrm{mM} \mathrm{Na}_{2} \mathrm{CO}_{3}$ eluent and a $25 \mu \mathrm{L}$ sample loop. The detection limits for selenate and perchlorate were $5 \mu \mathrm{g} / \mathrm{L}$ each. And those of acetate and nitrate were $0.5 \mathrm{mg} / \mathrm{L}$. All the regressions for experimental data were conducted by Sigmaplot software (Systat Software Inc., San Jose, CA, USA) based on the assumption of first-order removal [19].

\section{Results and Discussion}

\subsection{Appropriate Temperature for Selenate-Reducing Bacteria Acclimation in SBRs}

To increase the activity of selenate-reducing bacteria in the seed sludge, initial acclimation (phase 0 ) was conducted for about 50 days using two sets of triplicate SBRs. Figure 2a shows the variations of selenate concentrations at the very first batch of the SBRs. During nine days of phase 0 , only $27 \%$ of initial selenate $\left(0.72 \mathrm{mM} \mathrm{SeO}_{4}{ }^{2-}\right)$ was reduced on average at the SBRs of $25^{\circ} \mathrm{C}$. However, in the 
SBRs at $30{ }^{\circ} \mathrm{C}$ selenate was reduced to below detection level after nine days. This result indicates that $30{ }^{\circ} \mathrm{C}$, higher than room temperature, is more appropriate for the growth of selenate-reducing bacteria, which is consistent with previous literature $[14,20,21]$. With the revealed temperature condition, all the SBRs enriched selenate-reducing bacteria at $30{ }^{\circ} \mathrm{C}$ for the rest of phase 0 for further experiments.

At the end of phase 0 , monitoring results indicate that SBRs could reduce selenate $(0.9 \mathrm{mM})$ to below detection level in less than four hours. This enhancement indicates that phase 0 must have made the selenate-reducing bacteria successfully acclimated to start instantaneous selenate reduction right after fill-sequence without lag-period. Figure $2 \mathrm{~b}$ demonstrates that enriched microorganisms actively reduce selenate to $\mathrm{Se}^{0}$ biologically at the last batch of phase 0 , consistent with the literature $[6,14,22,23]$. Regression indicates that the observed selenate reduction rate was revealed as rapid as $0.96 \mathrm{~h}^{-1}$.
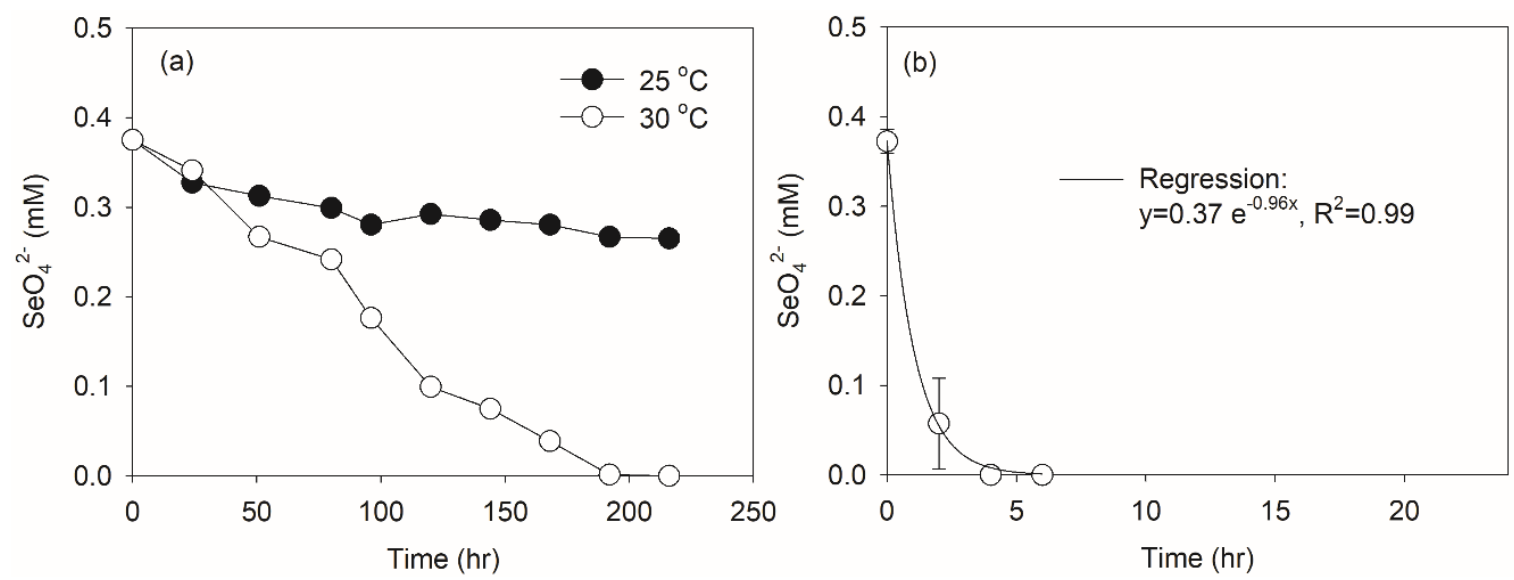

Figure 2. Dynamics of selenate concentration in SBRs of phase 0: (a) before acclimation, (b) after acclimation.

\subsection{Effect of Nitrate on Selenate Reduction}

At phase 1 and phase 2, this study tests the effect of most probable electron-competing anion, nitrate, on selenate reduction (Table 1$)$. We artificially constitute low (0.1 mM, phase 1$)$ and high ( $1 \mathrm{mM}$, phase 2$)$ selenate conditions for better interpretation. Figure 3 illustrates the dynamics of average $(n=3)$ selenate and nitrate in a whole sequence of SBRs at a steady state. When $3.8 \mathrm{mM}$ $\mathrm{CH}_{3} \mathrm{COO}^{-}$was added to $0.1 \mathrm{mM} \mathrm{SeO}_{4}{ }^{2-}$ (phase 1) as an excess electron donor in the presence of $0.96 \mathrm{mM} \mathrm{NO}_{3}{ }^{-}-\mathrm{N}$ (approximately 1:10 of influent $\mathrm{SeO}_{4}{ }^{2-}: \mathrm{NO}_{3}{ }^{-}$mole ratio), selenate and nitrate were simultaneously reduced to below detection level within six hours in SBRs (Figure 3a). In the case of phase 2, nitrate was completely reduced to below detection level, whereas a small amount of selenate was detected (0.02 mM, 98\% reduction) after six hours in SBRs (Figure 3b). Close to the end of the sequence, the selenate concentration decreased to below detection level.

Within the ratio of $\mathrm{SeO}_{4}{ }^{2-}: \mathrm{NO}_{3}{ }^{-}$between 1:1 and 1:10 tested in this study, both selenate and nitrate could be simultaneously reduced without significant inhibition. The selenate reduction rate was maintained at $0.55-0.57 \mathrm{~h}^{-1}$ regardless of initial concentration. This result indicates that selective enrichment and long acclimation (>30 days) could make selenate-reducing bacteria endure competitive inhibition, described previously [24]. In addition, it was noticed that the denitrification rate was not interrelated with the selenate concentration and kept the rate as $0.88 \mathrm{~h}^{-1}$ almost constantly, which supports simultaneous selenate and nitrate reduction under excess electron donor condition. 

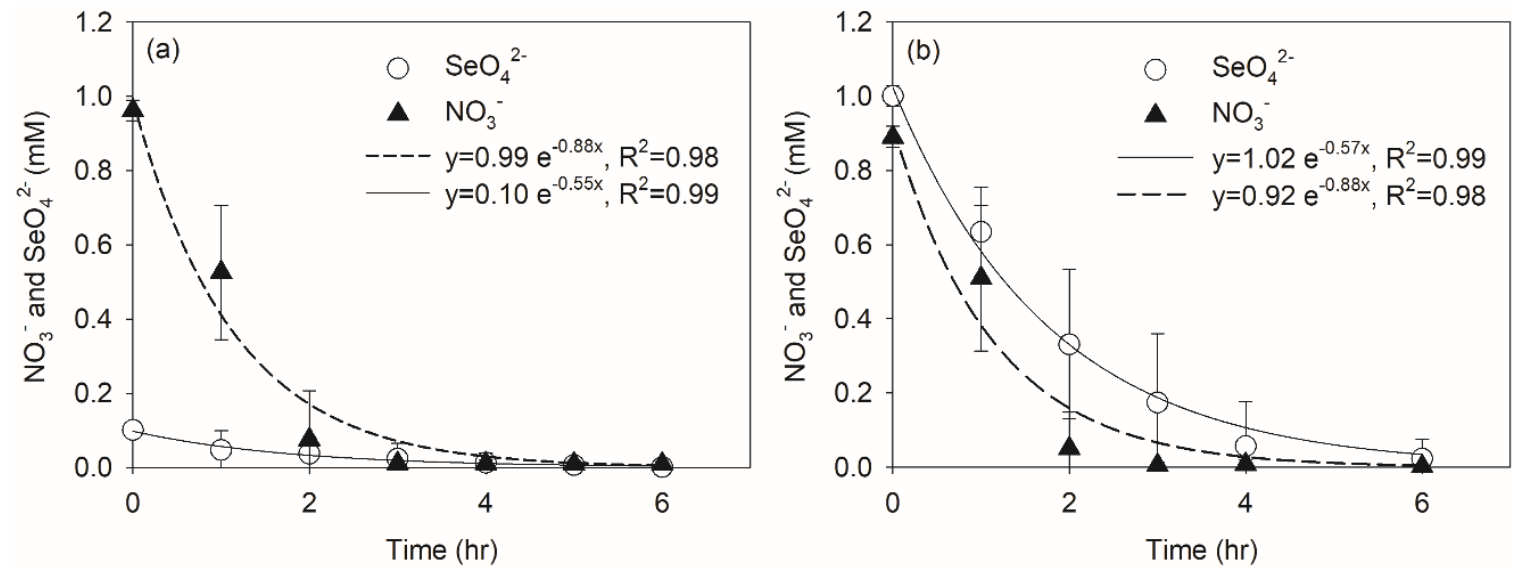

Figure 3. Dynamics of $\mathrm{SeO}_{4}{ }^{2-}$ and $\mathrm{NO}_{3}{ }^{-}$in SBRs: (a) $\mathrm{SeO}_{4}{ }^{2-}: \mathrm{NO}_{3}{ }^{-}=1: 10$ (phase 1) and (b) $\mathrm{SeO}_{4}{ }^{2-}: \mathrm{NO}_{3}{ }^{-}=1: 1$ (phase 2).

\subsection{Effect of External Carbon Limitation on Selenate Reduction}

Two sets of experiments were performed to investigate the effect of carbon source limitation on simultaneous selenate and nitrate reduction in the SBRs under low $(0.1 \mathrm{mM}$, phase 3$)$ and high selenate $(1 \mathrm{mM}$, phase 4$)$ conditions. Acetate concentration was limited to $0.8 \mathrm{mM}$ for phase 3 when the initial $\mathrm{SeO}_{4}{ }^{2-}$ concentration was $0.1 \mathrm{mM}$. Keeping the nitrate concentration as $1.0 \mathrm{mM}$ results in the decrease of $\mathrm{C}: \mathrm{N}$ ratio from 6.7:1 to 1.2:1 compared to phase 1. Phase 4 was conducted with $1 \mathrm{mM}$ of $\mathrm{SeO}_{4}{ }^{2-}$ reducing C:N ratio from 11.1:1 (phase 2) to 2.3:1 (phase 4). Phase 3 and phase 4 were directly comparable to phase 1 and phase 2, respectively. Figure $4 a, b$ demonstrate the variations of selenate, nitrate, and acetate concentrations in SBRs at phase 3 and 4, respectively, as described in Table 1.

Figure $4 \mathrm{a}$ (phase 3 ) shows that all the selenate was reduced instantaneously within two hours but the accompanying nitrate reduction significantly decelerates when the acetate was depleted at around $3 \mathrm{~h}$. Figure $4 \mathrm{~b}$ (phase 4 ) illustrates that nitrate reduction similarly stops when the acetate was depleted, but selenate reduction gradually progressed further despite the depletion of external carbon sources. This result indicates that denitrifying bacteria are more sensitive to electron donor compared to selenate-reducing bacteria. The increase of acetate concentration from $0.7 \mathrm{mM}$ to $1.2 \mathrm{mM}$ enhanced the nitrate reduction rate about $80 \%$ (from $0.79 \mathrm{hr}^{-1}$ to $1.42 \mathrm{hr}^{-1}$ ) at phase 4 but the nitrate reduction rate drastically ceased as the carbon source depleted. Selenate reduction rate was also decreased by $27.4 \%$ (from $0.95 \mathrm{~h}^{-1}$ to $0.69 \mathrm{~h}^{-1}$ ) possibly owing to inhibition associated with carbon source competition.
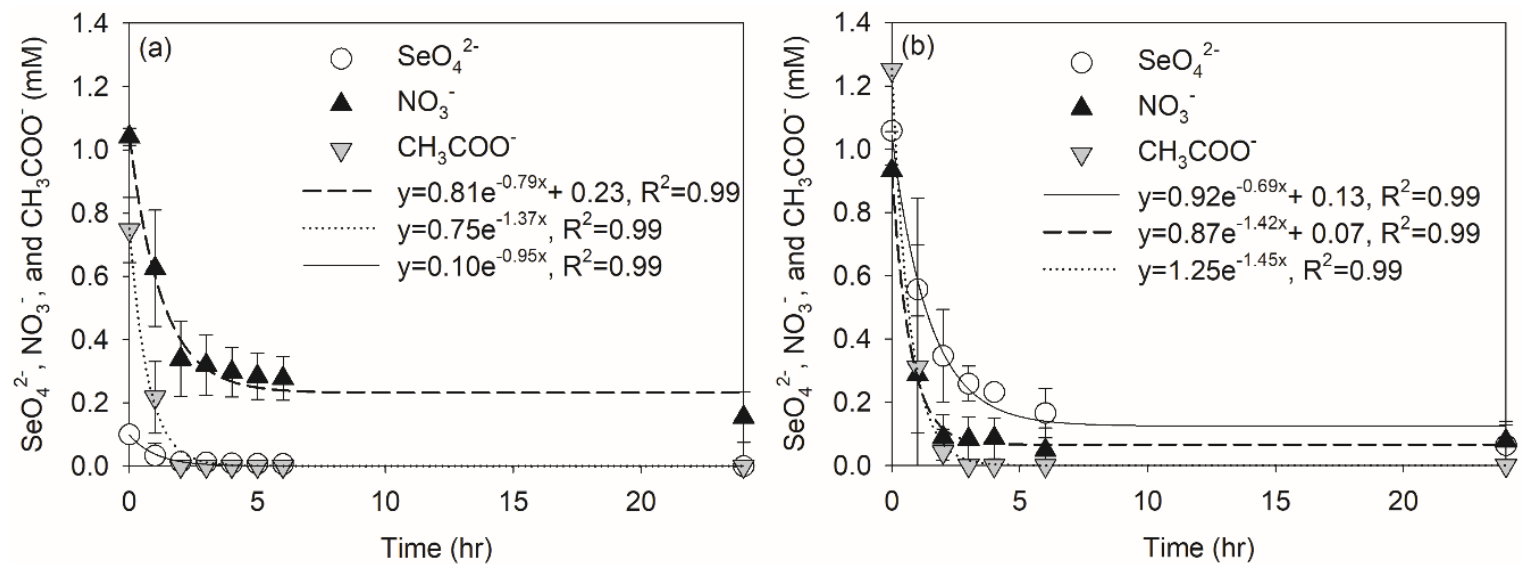

Figure 4. Dynamics of $\mathrm{SeO}_{4}{ }^{2-}, \mathrm{NO}_{3}{ }^{-}$, and $\mathrm{CH}_{3} \mathrm{COO}^{-}$under carbon limitation condition: (a) phase 3, (b) phase 4 .

When the selenate and nitrates are coexisting, selenate-reducing bacteria might present the ability to compete successfully for limited carbon resources like K-strategist microorganisms [25] while 
nitrate-reducing bacteria exploit relative offspring trends like r-strategist microorganisms [26] in this study. This result suggests that selenate-reducing bacteria has a more competitive advantage over withstanding harsh carbon-limiting condition than nitrate-reducing bacteria.

\subsection{Nitrate and Perchlorate Effect on Selenate Reduction in SBRs}

To investigate the effect of another oxyanion, perchlorate, on the simultaneous selenate reduction, SBRs were operated with a feed solution containing selenate $(0.1 \mathrm{mM})$, nitrate $(1.0 \mathrm{mM})$, and perchlorate $(0.15 \mathrm{mM})$ with an excess amount of external carbon source $(3.4 \mathrm{mM})$.

Figure 5 demonstrates that selenate and nitrate reduction are not affected by perchlorate significantly. It was observed that $38 \%$ of perchlorate (reduction rate of $0.02 \mathrm{~h}^{-1}$ ) can be reduced together with selenate and nitrate in the SBRs during $24 \mathrm{~h}$ of a sequence. This result indicates that dissimilatory perchlorate-reducing bacteria can grow together with selenate- and nitrate-reducing bacteria under anaerobic conditions if the carbon source (electron donor) is not limiting [27]. In this study, an insufficient population of perchlorate-reducing bacteria might have prevented the perchlorate from being a competitive inhibitor of selenate or nitrate reduction under excess electron donor conditions. Owing to perchlorate, the reduction rate of nitrate was significantly reduced from $0.9 \sim 1.4 \mathrm{~h}^{-1}$ (excess electron donor condition) to $0.5 \mathrm{~h}^{-1}$ at phase 5 . However, that of selenate did not decline but maintained to around $0.7-1.3 \mathrm{~h}^{-1}$, which evidences the ability of selenate-reducing bacteria to endure harmful perchlorate as well as electron donor competition without significant inhibition. This result also means that selenate-reducing bacteria can be dominantly enriched from activated sludge within a reasonable period of time if the carbon source is not limiting.

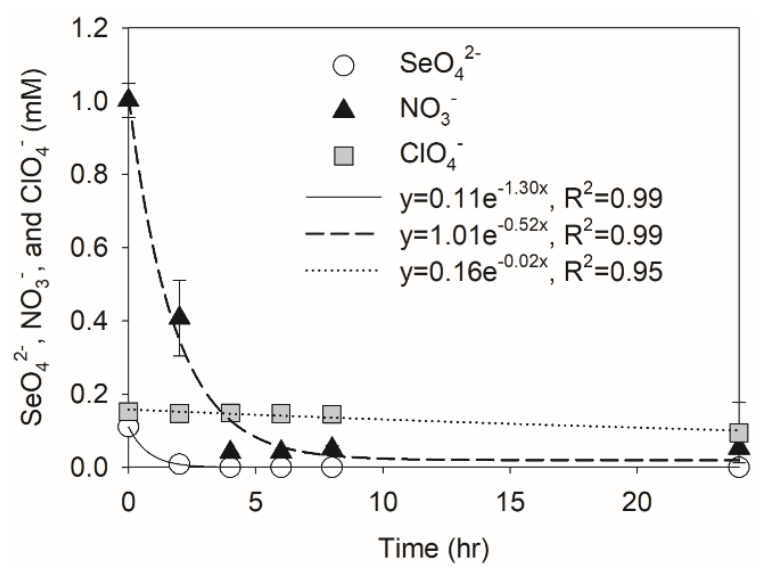

Figure 5. Dynamics of $\mathrm{SeO}_{4}{ }^{2-}, \mathrm{NO}_{3}{ }^{-}$, and $\mathrm{ClO}_{4}{ }^{-}$with excess carbon source in SBRs.

\section{Conclusions}

This research provides information about how competing anions, nitrate, and perchlorate, affect selenate reduction in SBRs which are seeded with activated sludge. Based on the observed data from this research, the following conclusions are drawn as below:

(1) SBRs can rapidly enrich selenate-reducing bacteria from the activated sludge by using the selective pressure of temperature $\left(30^{\circ} \mathrm{C}\right)$ and sufficient acclimation period of $>40$ days.

(2) Complete selenate and nitrate reduction can be accomplished simultaneously in anaerobic SBRs by supplying the excess amount of electron donor. Limitation of electron donor may decrease the activity of nitrate-reducing bacteria instantaneously while selenate-reducing bacteria responds slowly using the limited resources more efficiently.

(3) Coexistence of perchlorate in the feed did not affect selenate reduction significantly owing to the shortage of dissimilatory perchlorate reducing bacteria. However, together with selenate and nitrate, $38 \%$ of perchlorate could be reduced without acclimation when electron donor is not limited. 
Overall, these results evidence that selenate-reducing bacteria are capable of enduring competitions associated with other oxyanions reduction and electron donor without significant inhibition after appropriate acclimation. This study may contribute to understanding biological Se reduction better in relation to competing anions and electron donor conditions.

Author Contributions: H.C. conceived and designed the study. S.H.H. conducted the whole experiment. H.-W.K. and H.C. analyzed the data and wrote the paper. All authors have read and agreed to the published version of the manuscript.

Funding: This research was supported by Basic Science Research Program through the National Research Foundation of Korea (NRF) funded by the Ministry of Education (NRF-2016R1D1A1B03933921).

Conflicts of Interest: The authors declare no conflict of interest.

\section{References}

1. Stranges, S.; Navas-Acien, A.; Rayman, M.P.; Guallar, E. Selenium status and cardiometabolic health: state of the evidence. Nutr. Metab. Cardiovasc. Dis. 2010, 20, 754-760. [CrossRef] [PubMed]

2. USEPA. National Primary Drinking Water Regulations. Available online: https://www.epa.gov/groundwater-and-drinking-water/national-primary-drinking-water-regulations (accessed on 9 September 2019).

3. Lemly, A.D. Aquatic selenium pollution is a global environmental safety issue. Ecotox. Environ. Safe 2004, 59, 44-56. [CrossRef]

4. World Health Organization. Guidelines for Drinking-Water Quality: Fourth Edition Incorporating the First Addendum; World Health Organization Press: Geneva, Switzerland, 2017.

5. MOE. Drinking Water Regulation; Ministry of Environment: Seoul, Korea, 2019.

6. Nancharaiah, Y.V.; Lens, P.N. Selenium biomineralization for biotechnological applications. Trends Biotechnol. 2015, 33, 323-330. [CrossRef] [PubMed]

7. $\mathrm{CH} 2 \mathrm{MHill}$, Inc. Review of Available Technologies for the Removal of Selenium from Water; Selenium Working Group, North American Metals Council: Washington, WA, USA, 2010.

8. Snyder, M.M.; Um, W. Adsorption mechanisms and transport behavior between selenate and selenite on different sorbents. Int. J. Waste Resources 2014, 4, 1-8. [CrossRef]

9. Buchs, B.; Evangelou, M.W.; Winkel, L.H.; Lenz, M. Colloidal properties of nanoparticular biogenic selenium govern environmental fate and bioremediation effectiveness. Environ. Sci. Technol. 2013, 47, 2401-2407. [CrossRef]

10. Siddique, T.; Okeke, B.C.; Zhang, Y.; Arshad, M.; Han, S.K.; Frankenberger, W.T. Bacterial Diversity in Selenium Reduction of Agricultural Drainage Water Amended with Rice Straw. J. Environ. Qual. 2005, 34, 217-226. [CrossRef]

11. Zhang, Y.; Okeke, B.C.; Frankenberger, W.T. Bacterial reduction of selenate to elemental selenium utilizing molasses as a carbon source. Bioresour. Technol. 2008, 99, 1267-1273. [CrossRef]

12. Khamkhash, A.; Srivastava, V.; Ghosh, T.; Akdogan, G.; Ganguli, R.; Aggarwal, S. Mining-Related Selenium Contamination in Alaska, and the State of Current Knowledge. Minerals 2017, 7, 46. [CrossRef]

13. Tang, Q.; Liu, G.; Yan, Z.; Sun, R. Distribution and fate of environmentally sensitive elements (arsenic, mercury, stibium and selenium) in coal-fired power plants at Huainan, Anhui, China. Fuel 2012, 95, 334-339. [CrossRef]

14. Lenz, M.; Enright, A.M.; O'Flaherty, V.; van Aelst, A.C.; Lens, P.N. Bioaugmentation of UASB reactors with immobilized Sulfurospirillum barnesii for simultaneous selenate and nitrate removal. Appl. Microbiol. Biotechnol. 2009, 83, 377-388. [CrossRef]

15. Lai, C.Y.; Yang, X.; Tang, Y.; Rittmann, B.E.; Zhao, H.P. Nitrate shaped the selenate-reducing microbial community in a hydrogen-based biofilm reactor. Environ. Sci. Technol. 2014, 48, 3395-3402. [CrossRef] [PubMed]

16. Lai, C.Y.; Wen, L.L.; Shi, L.D.; Zhao, K.K.; Wang, Y.Q.; Yang, X.; Rittmann, B.E.; Zhou, C.; Tang, Y.; Zheng, P.; et al. Selenate and Nitrate Bioreductions Using Methane as the Electron Donor in a Membrane Biofilm Reactor. Environ. Sci. Technol. 2016, 50, 10179-10186. [CrossRef] [PubMed] 
17. Chung, J.; Rittmann, B.E.; Wright, W.F.; Bowman, R.H. Simultaneous bio-reduction of nitrate, perchlorate, selenate, chromate, arsenate, and dibromochloropropane using a hydrogen-based membrane biofilm reactor. Biodegradation 2007, 18, 199-209. [CrossRef] [PubMed]

18. Hageman, S.P.; van der Weijden, R.D.; Weijma, J.; Buisman, C.J. Microbiological selenate to selenite conversion for selenium removal. Water Res. 2013, 47, 2118-2128. [CrossRef]

19. Fujita, M.; Ike, M.; Kashiwa, M.; Hashimoto, R.; Soda, S. Laboratory-scale continuous reactor for soluble selenium removal using selenate-reducing bacterium, Bacillus sp. SF-1. Biotechnol. Bioeng. 2002, 80, 755-761. [CrossRef]

20. Wan, H.S.; Hao, O.J.; Kim, H. Environmental factors affecting selenite reduction by a mixed culture. J. Environ. Eng.-Asce 2001, 127, 175-178. [CrossRef]

21. Fujita, M.; Ike, M.; Nishimoto, S.; Takahashi, K.; Kashiwa, M. Isolation and characterization of a novel selenate-reducing bacterium, Bacillus sp. SF-1. J. Ferment. Bioeng. 1997, 83, 517-522. [CrossRef]

22. Astratinei, V.; van Hullebusch, E.; Lens, P. Bioconversion of Selenate in Methanogenic Anaerobic Granular Sludge. J. Environ. Qual. 2006, 35, 1873-1883. [CrossRef]

23. Lenz, M.; Smit, M.; Binder, P.; van Aelst, A.C.; Lens, P.N. Biological alkylation and colloid formation of selenium in methanogenic UASB reactors. J. Environ. Qual. 2008, 37, 1691-1700. [CrossRef]

24. Kashiwa, M.; Nishimoto, S.; Takahashi, K.; Ike, M.; Fujita, M. Factors affecting soluble selenium removal by a selenate-reducing bacterium Bacillus sp. SF-1. J. Biosci. Bioeng. 2000, 89, 528-533. [CrossRef]

25. Martín-Hernández, M.; Carrera, J.; Pérez, J.; Suárez-Ojeda, M.E. Enrichment of a K-strategist microbial population able to biodegrade p-nitrophenol in a sequencing batch reactor. Water Res. 2009, 43, 3871-3883. [CrossRef] [PubMed]

26. Dytczak, M.A.; Londry, K.L.; Oleszkiewicz, J.A. Activated sludge operational regime has significant impact on the type of nitrifying community and its nitrification rates. Water Res. 2008, 42, 2320-2328. [CrossRef] [PubMed]

27. Nozawa-Inoue, M.; Scow, K.M.; Rolston, D.E. Reduction of perchlorate and nitrate by microbial communities in vadose soil. Appl. Environ. Microbiol. 2005, 71, 3928-3934. [CrossRef] [PubMed]

(C) 2020 by the authors. Licensee MDPI, Basel, Switzerland. This article is an open access article distributed under the terms and conditions of the Creative Commons Attribution (CC BY) license (http://creativecommons.org/licenses/by/4.0/). 